BETRAYAL AND OTHER ACTS OF SUBVERSION 



\section{BETRAYAL AND OTHER ACTS OF SUBVERSION}

FEMINISM,SEXUAL POLITICS,

ASIAN AMERICAN

W OMEN'S LITERATURE

Leslie Bow 


\section{Copyright $($ C 2001 by Princeton University Press}

Published by Princeton University Press, 41 William Street,

Princeton, New Jersey 08540

In the United Kingdom: Princeton University Press,

3 Market Place, Woodstock, Oxfordshire OX20 1SY

All Rights Reserved

\section{Library of Congress Cataloging-in-Publication Data}

Bow, Leslie, 1962-

Betrayal and other acts of subversion : feminism, sexual politics,

Asian American women's literature / Leslie Bow.

p. $\mathrm{cm}$.

Includes bibliographical references and index.

ISBN 0-691-07092-X (alk. paper)

ISBN 0-691-07093-8 (pbk. : alk. paper)

1. American literature-Asian American authors-History and criticism. 2. American literature-Women authors-History and criticism. 3. Feminism and literature-United States. 4. Women and literature-United States. 5. Asian American women in literature. 6. Asian Americans in literature. 7. Sex role in literature. I. Title PS153.A84 B69 2000

$810.9^{\prime} 9287^{\prime} 08995-\mathrm{dc} 21 \quad 00-058488$

This book has been composed in Sabon

Printed on acid-free paper. $\infty$

www.pup.princeton.edu

Printed in the United States of America

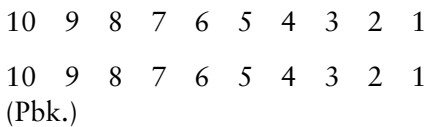

Acknowledgment goes to the following publishers for permission to reprint previously published material: "The Gendered Subject of Human Rights: Asian American Literature as Postcolonial Intervention.” Cultural Critique (Winter 1999): 37-78. "Le Ly Hayslip's Bad (Girl) Karma: Sexuality, National Allegory, and the Politics of Neutrality" published in Prose Studies, vol. 17, no. 1, pp. 141-60 by Frank Cass Publishers, London. "Cultural Conflict/Feminist Resolution in Amy Tan's The Joy Luck Club." In New Visions in Asian American Studies: Diversity, Community, and Power ed. Franklin Eng, Judy Yung, Stephen Fugita, and Elaine Kim, Washington State University Press, 1994. 235-47. "The Illusion of the Middle Way: Liberal Feminism and Biculturalism in Fifth Chinese Daughter." In Bearing Dreams, Shaping Visions: Asian Pacific American Perspectives ed. Linda A. Revilla, Gail M. Nomura, Shawn Wong, and Shirley Hune, Washington State University Press, 1993. 161-75. 
To Russ and Julian 
